\title{
Utility of a Bifunctional Tryptophan Pathway Enzyme for the Classification of the Herbicola-Agglomerans Complex of Bacteria $\dagger$
}

\author{
SUHAIL AHMAD AND ROY A. JENSEN* \\ Department of Microbiology and Cell Science, University of Florida, Gainesville, Florida 32611
}

\begin{abstract}
Bifunctional proteins are the result of relatively infrequent genetic events that are faithfully conserved. They are reliable markers that define phylogenetic clusters. The bifunctional protein anthranilate synthase: anthranilate 5-phosphoribosylpyrophosphate phosphoribosyltransferase (AS:PRT) separates two enteric clusters. Previously published data show that this bifunctional protein is present in the lineage shared by Escherichia coli, Salmonella typhimurium, Citrobacter freundii, Klebsiella pneumoniae, Enterobacter aerogenes, and Enterobacter cloacae, but is absent in Erwinia carotovora, Serratia marcescens, Proteus vulgaris, Morganella morganii, and Hafnia alvei. It has been postulated that aerogenic and anaerogenic strains of Enterobacter agglomerans belong to different groups, which correspond to the clusters mentioned above, respectively. In confirmation of this, we found that Enterobacter agglomerans ATCC 29915 (aerogenic) possesses bifunctional AS:PRT, whereas Enterobacter agglomerans ATCC $27155^{\mathrm{T}}$ (T = type strain) (anaerogenic) lacks AS:PRT. We also found that Erwinia herbicola $33243^{\mathrm{T}}$ lacks AS:PRT. Beji et al. (Int. J. Syst. Bacteriol. 38:77-88) recently showed that the type strains of Enterobacter agglomerans (ATCC 27155) and Erwinia herbicola (ATCC 33243) belong to the same genomic species. We suggest that Enterobacter agglomerans (= Erwinia herbicola) should be excluded from the genus Enterobacter. We further suggest that strains currently designated Enterobacter agglomerans can be grouped with Erwinia herbicola or with the enteric cluster containing Enterobacter depending upon whether bifunctional AS:PRT is absent or present, respectively.
\end{abstract}

The Approved Lists of Bacterial Names includes seven names that contain strains belonging to the Enterobacter agglomerans-herbicola group of Erwinia species (21). Three species are listed in the herbicola group of Erwinia species (Erwinia herbicola, Erwinia stewartii, and Erwinia uredovora) in Bergey's Manual of Determinative Bacteriology, 8th ed. (18). Ewing and Fife (10) suggested the name Enterobacter agglomerans for some strains belonging to the herbicola-agglomerans complex. These authors further classified the strains belonging to Enterobacter agglomerans into seven anaerogenic biogroups and four aerogenic biogroups. The majority of strains are anaerogenic $(10,20)$. When the biochemical characteristics of the aerogenic and anaerogenic strains of Enterobacter agglomerans were compared with the characteristics of strains of Enterobacter cloacae, it was found that the strains belonging to the aerogenic biogroups are more similar to the Enterobacter cloacae strains than the strains belonging to the anaerogenic biogroups are $(10,20)$. The other three species listed on the Approved Lists of Bacterial Names for the herbicola-agglomerans group of bacteria are Escherichia adecarboxylata, Erwinia ananas, and Erwinia milletiae.

The strains identified as Erwinia herbicola are isolated from plant lesions, from plant surfaces, and, occasionally, from water and air (19). Strains assigned to Enterobacter agglomerans have been isolated mainly from plants, soil, foodstuffs, and human and animal sources (20). Ewing and Fife (10) proposed that the strains isolated from plant lesions and surfaces be placed in the genus Erwinia, while those isolated from clinical sources be designated Enterobacter agglomerans because of their conformity with the genus Enterobacter. It currently is difficult to distinguish strains from different sources due to the diversity in this complex group of organisms $(7,11)$. A recent study carried out on 124

\footnotetext{
* Corresponding author.

$\dagger$ Florida Agriculture Experiment Station Journal Series no. 9224.
}

strains belonging to this complex (8) in which levels of deoxyribonucleic acid relatedness were determined revealed that strains identified as Enterobacter agglomerans belong to more than 12 species (i.e., different deoxyribonucleic acid hybridization groups).

Bifunctional proteins have proven to be very stable characters. Comprehensive comparative enzymological studies of aromatic amino acid biosynthesis carried out in our laboratory have shown that bifunctional proteins are highly conserved characters since not a single instance of their loss has been recorded in phylogenetic clusters containing them (1-3, 16). Escherichia coli possesses at least four bifunctional proteins that participate in the biosynthesis of aromatic amino acids, and these bifunctional proteins enjoy different levels of hierarchical distribution $(1,9,16,23)$. The bifunctional $P$ protein (chorismate mutase-P:prephenate dehydratase, E.C.5.4.99.5-4.2.1.51) of phenylalanine biosynthesis is of ancient origin and is present in all the members of the superfamily A (purple nonsulfur II bacteria) and superfamily B (purple sulfur bacteria) subdivisions of gramnegative bacteria $(1,2,16)$. The bifunctional $\mathrm{T}$ protein (chorismate mutase-T:cyclohexadienyl dehydrogenase, E.C.5.4.99.5-1.3.1.12) of tyrosine biosynthesis and the bifunctional phophoribosylanthranilate isomerase:indoleglycerolphosphate synthase (E.C.4.1.1.48) of tryptophan biosynthesis are of recent origin and have been found in all members of the enteric lineage (which includes traditional enteric bacteria and the genera Aeromonas and Alteromonas) $(1,3,9)$. The second bifunctional protein of tryptophan biosynthesis, anthranilate synthase:anthranilate 5-phosphoribosylpyrophosphate phosphoribosyltransferase (E.C.4.1.3. 27-2.4.2.18) (AS:PRT) is of much more recent origin. Its presence is limited to the genera Escherichia, Salmonella, Citrobacter, Klebsiella, and Enterobacter, and it is absent from other enteric bacteria $(13,17,23)$.

Since the bifunctional protein AS:PRT is known to be present in two Enterobacter species (Enterobacter aerogenes and Enterobacter cloacae) but is absent from the only 
Erwinia species studied (Erwinia carotovora) $(17,23)$, this protein appeared to be a fortuitous probe for testing the proposed phylogenetic separation of aerogenic and anaerogenic biogroups of Enterobacter agglomerans. We studied the presence or absence of bifunctional AS:PRT in the type strain of Erwinia herbicola and in single strains representing the aerogenic and anaerogenic biogroups of Enterobacter agglomerans, and the results which we obtained are presented in this paper.

\section{MATERIALS AND METHODS}

Bacterial strains and culture conditions. Enterobacter agglomerans ATCC 29915 (aerogenic strain), Enterobacter agglomerans ATCC $27155^{\mathrm{T}}$ ( $\mathrm{T}=$ type strain) (anaerogenic strain), and Erwinia herbicola ATCC $33243^{\mathrm{T}}$ were obtained from the American Type Culture Collection, Rockville, Md. Enterobacter agglomerans ATCC $29915\left(26^{\circ} \mathrm{C}\right)$, Enterobacter agglomerans ATCC $27155^{\mathrm{T}}\left(30^{\circ} \mathrm{C}\right)$, and Erwinia herbicola ATCC $33243^{\mathrm{T}}\left(26^{\circ} \mathrm{C}\right)$ were grown on M9 medium as described by Winkler and Stuckman (22), except that the medium was supplemented with $1.0 \%$ (wt/vol) acid-hydrolyzed casein (Difco Laboratories, Detroit, Mich.). Inclusion of acid-hydrolyzed casein in the growth medium results in derepression of tryptophan pathway enzymes since the faster growth rate and the presence of all amino acids except L-tryptophan make tryptophan rate limiting to growth (4, 17). The organisms were grown to the late exponential phase, washed twice with $50 \mathrm{mM}$ potassium phosphate buffer ( $\mathrm{pH} 7.0$ ) containing $1 \mathrm{mM}$ dithiothreitol (buffer $\mathrm{A}$ ), and stored at $-80^{\circ} \mathrm{C}$ until they were used.

Preparation of cell extracts and enzyme assays. Cell pellets were suspended in buffer $A$, disrupted by sonication (three 25 -s bursts of ultrasound energy [100 W]), and centrifuged at $105,000 \times g$ for $1 \mathrm{~h}$. The resulting supernatant was passed through a Sephadex G-25 column $(1.5$ by $20.0 \mathrm{~cm})$ equilibrated in $10 \mathrm{mM}$ potassium phosphate buffer $(\mathrm{pH} 7.0)$ containing $1 \mathrm{mM}$ dithiothreitol (buffer $\mathrm{B}$ ). The proteincontaining fractions were pooled and were termed the crude extract.

Anthranilate synthase (AS) activity with glutamine as the amino group donor was assayed at $37^{\circ} \mathrm{C}$ as described by Henderson et al. (13). The reaction mixture (final volume, $0.2 \mathrm{ml}$ ) contained buffer $\mathrm{A}, 5 \mathrm{mM}$ glutamine, $2 \mathrm{mM} \mathrm{MgSO}_{4}$, $0.5 \mathrm{mM}$ potassium chorismate, and enzyme. The reaction was started by adding chorismate, and the continuous formation of anthranilate was followed by using an AmincoBowman spectrophotofluorometer (excitation at $325 \mathrm{~nm}$, emission at $400 \mathrm{~nm}$ ).

Anthranilate-5-phosphoribosylpyrophosphate phosphoribosyltransferase (PRT) activity was assayed by following the disappearance of anthranilate at $37^{\circ} \mathrm{C}$ as described by Henderson et al. (13). The reaction mixture (final volume, $0.2 \mathrm{ml}$ ) contained buffer $\mathrm{A}, 2 \mathrm{mM} \mathrm{MgSO}_{4}, 30 \mu \mathrm{M}$ anthranilate, $1 \mathrm{mM}$ 5-phosphoribosyl-1-pyrophosphate, and enzyme. The reaction was started by adding 5-phosphoribosyl-1-pyrophosphate, and the disappearance of anthranilate was monitored with an Aminco-Bowman spectrophotofluorometer (excitation at $325 \mathrm{~nm}$, emission at $400 \mathrm{~nm}$ ). The rate of formation or disappearance of anthranilate was calculated by using the relative fluorescence values obtained from authentic samples of anthranilate.

Protein in the crude extract was estimated by the method of Bradford (6), using bovine serum albumin as the standard protein.

DE52 column chromatography. Approximately $80 \mathrm{mg}$ of crude-extract protein was applied to a diethylaminoethyl
TABLE 1. Specific activities of AS and PRT in crude extracts

\begin{tabular}{llr}
\hline \multirow{2}{*}{ Organism } & \multicolumn{2}{c}{ Sp act $^{a}$} \\
\cline { 2 - 3 } & $\mathrm{AS}^{b}$ & PRT \\
\hline Enterobacter agglomerans ATCC 29915 & 23.0 & 6.1 \\
Enterobacter agglomerans ATCC $27155^{\mathrm{T}}$ & 17.9 & 15.4 \\
Erwinia herbicola ATCC 33243 $^{\mathrm{T}}$ & 66.2 & 17.4 \\
\hline
\end{tabular}

${ }^{a}$ Specific activities are expressed as nanomoles of anthranilate formed (for AS) or consumed (for PRT) per minute per milligram of protein.

${ }^{b}$ AS activity was assayed by using glutamine as the amino group donor (amidotransferase).

cellulose column (type DE52; 1.5 by $20.0 \mathrm{~cm}$ ) equilibrated in buffer B. The column was washed with 2 bed volumes of the equilibration buffer, and then the bound proteins were eluted with $300 \mathrm{ml}$ of a linear gradient of $\mathrm{KCl}(0.0$ to $0.5 \mathrm{M})$ contained in the equilibration buffer. The fractions $(2.2 \mathrm{ml})$ collected were assayed for absorbance at $280 \mathrm{~nm}$ and for AS and PRT activities.

Biochemicals and chemicals. Amino acids, bovine serum albumin, dithiothreitol, anthranilate, 5-phosphoribosyl-1-pyrophosphate, and Sephadex G-25 were obtained from Sigma Chemical Co., St. Louis. Mo.). DE52 was purchased from Whatman, Inc., Clifton, N.J. Chorismate was isolated from the accumulation medium of a triple auxotroph (strain 62-1) of Klebsiella pneumoniae and was purified as the free acid (12). All other chemicals were standard reagent grade.

\section{RESULTS AND DISCUSSION}

Both AS and PRT activities were readily detected in crude extracts prepared from Enterobacter agglomerans ATCC 29915 (aerogenic strain), Enterobacter agglomerans ATCC $27155^{\mathrm{T}}$ (anaerogenic strain), and Erwinia herbicola $33243^{\mathrm{T}}$. The specific activities of AS and PRT from these organisms are shown in Table 1 . DE52 column chromatography was used to fractionate these enzyme activities in order to demonstrate the presence or absence of bifunctional AS: PRT in these organisms.

In Escherichia coli, Salmonella typhimurium, and other enteric bacteria that possess bifunctional AS:PRT, two forms of this bifunctional protein have been reported $(14,15$, 17 ), a soluble form and a particulate form associated with some unidentified cellular component. The PRT activity in the particulate form of bifunctional AS:PRT from these organisms has been reported to be greatly diminished under in vitro assay conditions $(14,15,17)$.

The elution profiles of the AS and PRT activities following DE52 chromatography of the crude extracts prepared from Enterobacter agglomerans ATCC 29915 are shown in Fig. 1a. Two peaks of AS activity eluted. A broadly shaped profile of activity appeared early in the gradient fractions, followed by a sharp, trailing peak of activity. The two AS activity peaks coincided with two peaks of PRT activity. However, the PRT activity was relatively low in the leading eluate band. The coincident elution of AS and PRT activity peaks from Enterobacter agglomerans ATCC 29915 indicates that bifunctional AS:PRT is present in this organism. The first broad peak of bifunctional AS:PRT from Enterobacter agglomerans ATCC 29915 (Fig. 1a) reflects the particulate form of this bifunctional protein, which was present in the crude extracts either due to the presence of lighter membrane fractions that did not sediment during high-speed centrifugation or due to dissociation from the membranes during sonic treatment. 


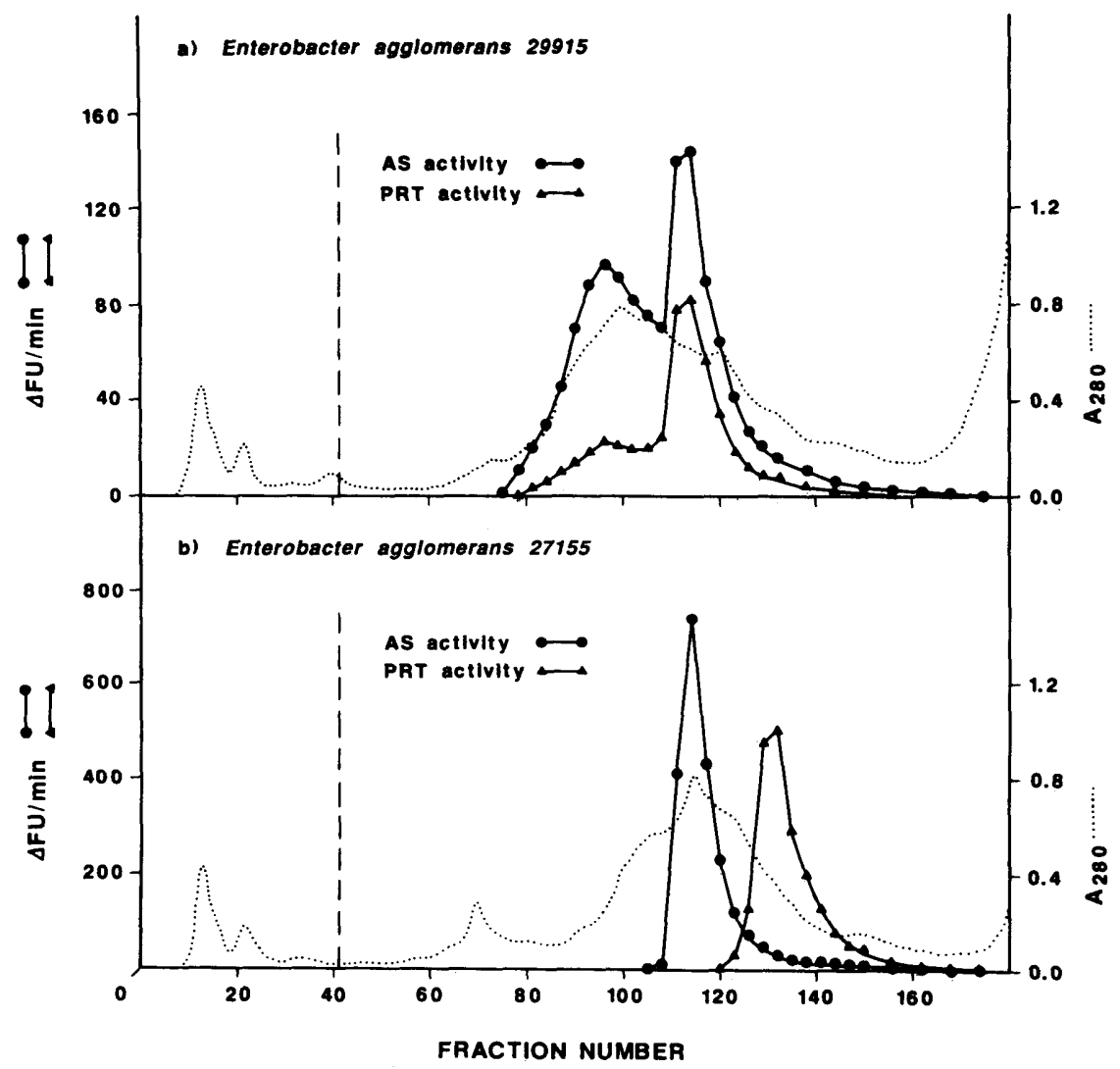

FIG. 1. Elution profiles of AS and PRT activities following DE52 column chromatography of crude extracts prepared from Enterobacter agglomerans ATCC 29915 (a) and Enterobacter agglomerans ATCC $27155^{\mathrm{T}}$ (b). DE52 column chromatography was performed as described in Materials and Methods. The vertical dashed lines indicate the onset of gradient elution. AS and PRT activities are expressed as changes in fluorescence units $(\Delta \mathrm{FU})$ per minute. A change of 252 fluorescence units per min corresponds to $1 \mathrm{nmol}$ of anthranilate formed or consumed per min. The distribution of proteins (as monitored by absorbance at $280 \mathrm{~nm}$ [ $\left.\mathrm{A}_{280}\right]$ ) is shown by dotted lines.

A single sharp peak of AS activity eluted in the gradient fractions when crude extracts prepared from Enterobacter agglomerans ATCC $27155^{\mathrm{T}}$ (anaerogenic strain) were used for DE52 column chromatography (Fig. 1b). The PRT activity also eluted as a single sharp peak of activity (Fig. 1b). The two activity peaks were well separated in the gradient fractions, thus showing that Enterobacter agglomerans ATCC $27155^{\mathrm{T}}$ possesses monofunctional AS and monofunctional PRT instead of bifunctional AS:PRT.

The type strain of Erwinia herbicola (ATCC 33243) was also used to fractionate AS and PRT activities by DE52 column chromatography (Fig. 2). Again, single, sharp, wellseparated peaks of AS and PRT activities eluted in the gradient fractions. These results showed that Erwinia herbicola ATCC $33243^{\mathrm{T}}$ lacks bifunctional AS:PRT.

The data obtained in this study, together with previous observations made with other enteric bacteria, are summarized in Table 2. Two other Enterobacter species (Enterobacter aerogenes and Enterobacter cloacae) possess bifunctional AS:PRT, while the only other Erwinia species studied (Erwinia carotovora) possesses monofunctional species of AS and PRT. Ewing and Fife (10) reported that $80 \%$ of strains belonging to the species Enterobacter agglomerans are anaerogenic, while the remaining strains are aerogenic. Biochemical studies carried out on these organisms have shown that the aerogenic strains resemble Enterobacter cloacae and other Enterobacter species more closely than they resemble anaerogenic strains $(10,20)$. On the other hand, some biochemical characteristics of the anaerogenic strains (such as yellow pigmentation) resemble those typically associated with Erwinia species $(19,20)$. Indeed, some of the strains belonging to Enterobacter agglomerans were initially placed in the genus Erwinia $(7,11)$. In this regard, it is striking that the aerogenic Enterobacter agglomerans strain which we studied (ATCC 29915) possesses bifunctional AS:PRT, a character also shared by other Enterobacter species, while the anaerogenic Enterobacter agglomerans strain (ATCC $27155^{\mathrm{T}}$ ) possesses monofunctional AS and PRT, characters present in Erwinia herbicola and Erwinia carotovora. More strains will need to be examined to determine whether a perfect correspondence exists between aerogenic physiology and the bifunctional AS:PRT protein.

Brenner et al. (8) studied the herbicola-agglomerans complex of strains by using deoxyribonucleic acid relatedness and phenotypic characteristics. These authors concluded that these criteria could not yield an adequate classification, largely due to the extreme diversity of the component strains. They emphasized the need for other in-depth studies with these organisms for a meaningful classification. Beji et al. (5) recently found that Enterobacter agglomerans ATCC $27155^{\mathrm{T}}$ and Erwinia herbicola ATCC $33243^{\mathrm{T}}$ belong to a common genomic species (which corresponds to group XIII of Brenner et al.). On the other hand, Enterobacter agglomerans ATCC 29915 belongs to group XII of Brenner et al. Although in our study we used only three strains belonging to this complex, we capitalized upon the utility of a very 


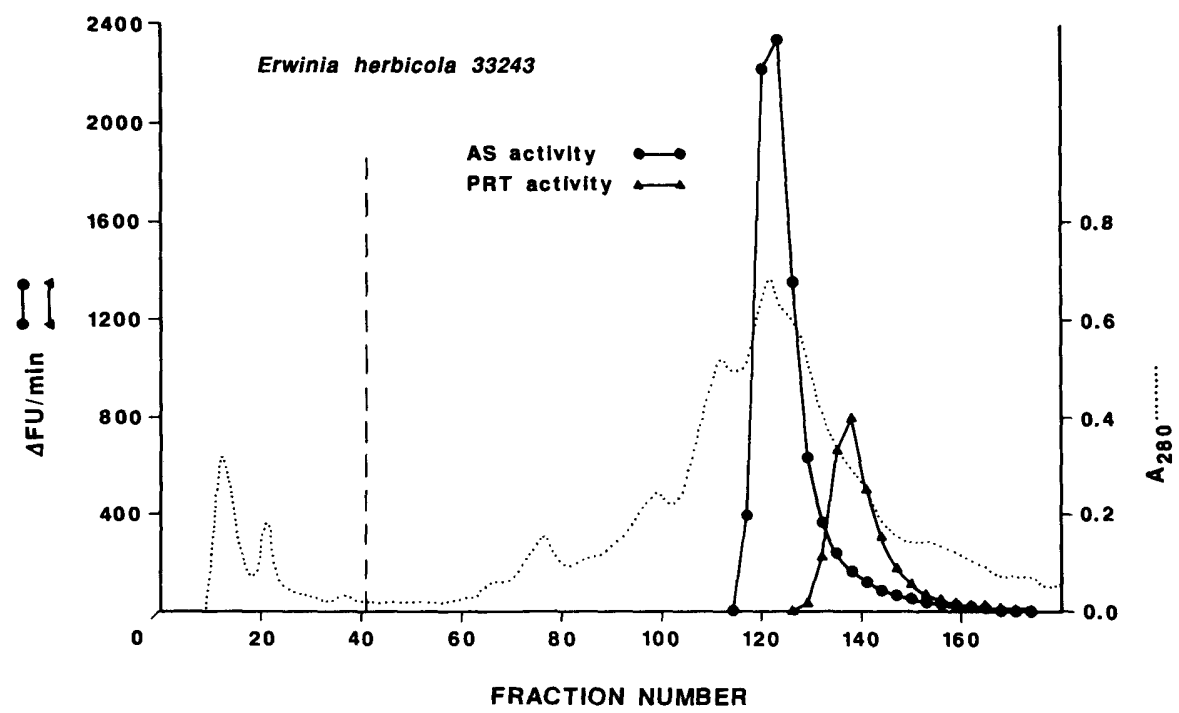

FIG. 2. Elution profiles of AS and PRT activities following DE52 column chromatography of crude extract prepared from Erwinia herbicola ATCC $33243^{\mathrm{T}}$. For details see the legend to Fig. 1 .

powerful tool for identification of phylogenetic clusters. A strong selective pressure for maintenance of bifunctional proteins, once evolved, undoubtedly exists (as evidenced by our comprehensive studies carried out on other bifunctional proteins [1-3]). This approach is, of course, limited to delineation of a cluster sharing a common ancestor in which the fortuitous evolution of a bifunctional protein occurred.

On the basis of the results described above, a clear rationale exists in favor of excluding Entrobacter agglomerans (= Erwinia herbicola) from the genus Enterobacter. Of the options advanced by Beji et al. (5), our data favor renaming the species defined by Enterobacter agglomerans ATCC $27155^{\mathrm{T}}$ and the genotypic group provisionally called deoxyribonucleic acid hybridization group 27155 as Erwinia agglomerans. Of those strains currently bearing the name

TABLE 2. Presence or absence of bifunctional AS:PRT in enteric bacteria

\begin{tabular}{lccc}
\hline \multicolumn{1}{c}{ Enteric bacterium } & \multicolumn{2}{c}{ Presence of: } & \\
\cline { 2 - 4 } & $\begin{array}{c}\text { Bifunctional } \\
\text { AS:PRT }\end{array}$ & $\begin{array}{c}\text { Monofunctional } \\
\text { AS and PRT }\end{array}$ & \\
\hline Escherichia coli & $+^{a}$ & - & 15,23 \\
Salmonella typhimurium & + & - & 14,23 \\
Citrobacter freundii & + & - & 17,23 \\
Klebsiella pneumoniae & + & - & 23 \\
Enterobacter aerogenes & + & - & 23 \\
Enterobacter cloacae & + & - & 17,23 \\
Enterobacter agglomerans & + & - & This paper \\
$\quad$ ATCC 29915 & - & & This paper \\
Enterobacter agglomerans & - & + & This paper \\
$\quad$ ATCC 27155 & - & + & 17,23 \\
Erwinia herbicola ATCC & - & + & 17,23 \\
$\quad 33243$ & & + & 17,23 \\
Erwinia carotovora & - & + & 17,23 \\
Serratia marcescens & - & + & 17,23 \\
Serratia liquefaciens & - & + & 17,23 \\
Serratia rubidaea & - & + & 17,23 \\
Proteus vulgaris & - & &
\end{tabular}

$a+$, Present; - , absent.
Enterobacter agglomerans that possess the bifunctional AS:PRT protein, placement within the genus Enterobacter (or at least within the cluster containing Escherichia-Salmonella-Citrobacter-Klebsiella and Enterobacter) is indicated. It seems likely that the subdivision of contemporary Enterobacter agglomerans strains into aerogenic and anaerogenic strains will prove to correspond to the presence and absence, respectively, of bifunctional AS:PRT.

\section{ACKNOWLEDGMENT}

This study was supported by grant DMB-8615314 from the National Science Foundation.

\section{LITERATURE CITED}

1. Ahmad, S., and R. A. Jensen. 1986. The evolutionary history of two bifunctional proteins that emerged in the purple bacteria. Trends Biochem. Sci. 11:108-112.

2. Ahmad, S., and R. A. Jensen. 1988. New prospects for deducing the evolutionary history of metabolic pathways in prokaryotes: aromatic biosynthesis as a case-in-point. Origins Life 18:41-57.

3. Ahmad, S., and R. A. Jensen. 1988. The phylogenetic origin of the bifunctional tyrosine-pathway protein in the enteric lineage of bacteria. Mol. Biol. Evol. 5:282-297.

4. Ahmad, S., J. L. Johnson, and R. A. Jensen. 1987. The recent evolutionary origin of the phenylalanine-sensitive isozyme of 3-deoxy-D-arabino-heptulosonate 7-phosphate synthase in the enteric lineage of bacteria. J. Mol. Evol. 25:159-167.

5. Beji, A., J. Mergaert, F. Gavini, D. Izard, K. Kersters, H. Leclerk, and J. De Ley. 1988. Subjective synonymy of Erwinia herbicola, Erwinia milletiae, and Enterobacter agglomerans and redefinition of the taxon by genotypic and phenotypic data. Int. J. Syst. Bacteriol. 38:77-88.

6. Bradford, M. M. 1976. A rapid and sensitive method for the quantitation of microgram quantities of proteins utilizing the principle of protein-dye binding. Anal. Biochem. 72:248-254.

7. Brenner, D. J. 1981. The genus Enterobacter p. 1173-1180. In M. P. Starr, H. Stolp, H. G. Truper, A. Balows, and H. G. Schlegel (ed.), The prokaryotes. Springer-Verlag, Berlin.

8. Brenner, D. J., G. R. Fanning, J. K. L. Knutson, A. G. Steigerwalt and M. I. Krichevsky. 1984. Attempts to classify herbicola group-Enterobacter agglomerans strains by deoxyribonucleic acid hybridization and phenotypic tests. Int. J. Syst. Bacteriol. 34:45-55.

9. Crawford, I. P. 1980. Gene fusions in the tryptophan pathway: 
tryptophan synthase and phosphoribosyl-anthranilate isomerase:indoleglycerolphosphate synthase, p. 151-173. In H. Bisswanger and E. Schmincke-Ott (ed.), Multifunctional proteins. John Wiley \& Sons, Inc., New York.

10. Ewing, W. H., and M. A. Fife. 1972. Enterobacter agglomerans (Beijerinck) comb. nov. (the Herbicola-Lathyri bacteria). Int. J. Syst. Bacteriol. 22:4-11.

11. Farmer, J. J., III, B. R. Davis, F. W. Hickman-Brenner, A. McWhorter, G. P. Huntley-Carter, M. A. Asbury, C. Riddle, H. G. Wathen-Grady, C. Elias, G. R. Fanning, A. G. Steigerwalt, C. M. O'Hara, G. K. Morris, P. B. Smith, and D. J. Brenner. 1985. Biochemical identification of new species and biogroups of Enterobacteriaceae isolated from clinical specimens. J. Clin. Microbiol. 21:46-76.

12. Gibons, F. 1970. Preparation of chorismic acid. Methods Enzymol. 17A:362-364.

13. Henderson, E. J., H. Nagano, H. Zalkin, and L. H. Hwang. 1970 The anthranilate synthase-anthranilate 5-phosphoribosylpyrophosphate phosphoribosyltransferase aggregate: purification of the aggregate and regulatory properties of anthranilate synthetase. J. Biol. Chem. 245:1416-1423.

14. Hwang, L. H., and H. Zalkin. 1971. Multiple forms of anthranilate synthetase-anthranilate 5-phosphoribosylpyrophosphate phosphoribosyltransferase from Salmonella typhimurium. J. Biol. Chem. 246:2338-2345.

15. Ito, J., and C. Yanofsky. 1969. Anthranilate synthetase, an enzyme specified by tryptophan operon of Escherichia coli: comparative studies on the complex and the subunits. J. Bacteriol. 97:734-742.

16. Jensen, R. A. 1985 . Biochemical pathways in prokaryotes can be traced backward through evolutionary time. Mol. Biol. Evol.
2:92-108.

17. Largen, M., and W. L. Belser. 1975. Tryptophan biosynthetic pathway in Enterobacteriaceae: some physical properties of enzymes. J. Bacteriol. 121:239-249.

18. Lelliott, R. A. 1974. Genus XII. Erwinia Winslow, Broadhurst, Buchanan, Krumwiede, Rogers and Smith 1920, 209, p. 332 339. In R. E. Buchanan and N. E. Gibbons (ed.), Bergey's manual of determinative bacteriology, 8th ed. The Williams \& Wilkins Co., Baltimore.

19. Lelliott, R. A., and R. S. Dickey. 1985. Genus VII. Erwinia Winslow, Broadhurst, Buchanan, Krumwiede, Rogers and Smith, 1920, 209, p. 469-476. In N. R. Krieg and J. G. Holt (ed.), Bergey's manual of systematic bacteriology, vol. 1. The Williams \& Wilkins Co., Baltimore.

20. Richard, C. 1985. Genus VI. Enterobacter Hormaeche and Edwards 1960, 72, Nom. cons. opin. 28, Jud. Comm. 1963, 38, p. 465-469. In N. R. Krieg and J. G. Holt (ed.), Bergey's manual of systematic bacteriology, vol. 1. The Williams \& Wilkins Co., Baltimore.

21. Skerman, V. B. D., V. McGowan, and P. H. A. Sneath (ed.). 1980. Approved lists of bacterial names. Int. J. Syst. Bacteriol. 30:225-420.

22. Winkler, U. K., and M. Stuckman. 1979. Glycogen, hyaluronate, and some other polysaccharides greatly enhance the formation of exolipase by Serratia marcescens. J. Bacteriol. 138:663-670.

23. Zalkin, H. 1980 . Anthranilate synthase: relationship between bifunctional and monofunctional enzymes, p. 123-149. In $\mathrm{H}$. Bisswanger and E. Schmincke-Ott (ed.), Multifunctional proteins. John Wiley \& Sons, Inc., New York. 